\title{
AN ADDITIONAL HEAD OF THE M. FLEXOR DIGITORUM SUPERFICIALIS FOUND IN A GOAT
}

\author{
V. RAJTOVÁ, J. DANKO \\ Department of Anatomy and Histology, University of Veterinary Medicine, Košice, Slovak Republic
}

Received April 20, 1998

Accepted June 5, 1998

\begin{abstract}
Rajtová V., J. Danko: An Additional Head of the m. flexor digitorum superficialis Found in a Goat. Acta vet. Brno 1998, 67: 79-81.

The finding of an additional head for the $\mathrm{m}$. flexor digitorum superficialis on the hind limb of one male goat is documented here. Its possible classification is discussed.
\end{abstract}

Hind limb, m. flexor digitorum superficialis. caput accessorium, male goat

The m. triceps surae occurs on the laterocaudal part of the crus in domestic mammals. In most of them, it consists of the m. gastrocnemius and the m. soleus. Exceptions can be found in the dog family in which the more laterally placed $\mathrm{m}$. soleus is absent (Ellenberger and Baum 1943; Kolda 1950; Koch 1960; Schwarze 1960; Getty 1975; Nickel et al. 1986; Dyce et al. 1987; Evans 1993). In cats, however, this muscle is present at the same place as in other domestic mammals ( Nickel et al. 1986; Spoor and Badoux 1989; König 1992). When dissecting the hind limb muscles in some species of carnivores, S poor and Badoux (1989) found on the lateral part of the m. flexor digitorum superficials an additional head of various sizes arising from the superficial flexor of digits, and immersing by means of a tendon into the tendo calcaneus communis. On the basis of vascularisation, innervation and topography, Spoor and B adoux (1989) consider this additional head as homologous with the missing $\mathrm{m}$. soleus.

To our knowledge, division of the $\mathrm{m}$. flexor digitorum superficialis in a way similar to that found in the dog or hyena has not been found in domesticated mammals.

\section{Materials and Methods}

A macroscopic dissection of muscles in the regio cruris in 58 adult sheep and 25 goats of both sexes was carried out. Great attention was paid to the $\mathrm{m}$. triceps surae and $\mathrm{m}$. flexor digitorum superficialis.

\section{Results}

In all the sheep and goats, the $\mathrm{m}$. triceps surae consisted of two heads m. gastrocnemius situated on the crural caudal part and a small but distinct m. soleus (Plate I., Fig. 1/c). The muscle belly of the $\mathrm{m}$. flexor digitorum superficialis was homogenous and undivided. Of all the small ruminant material used, there was a well-developed muscular strip on both hind limbs covered by the caput laterale $\mathrm{m}$. gastrocnemii in only one adult male goat. It emerged 
from the perimysium of the lateral part of the belly of the $\mathrm{m}$. flexor digitorum superficialis (Fig. 2/h). Distally, it formed a narrow tendon, which by means of two short branches (Plate II., Fig. 3/c, arrows) terminated in the tendo calcaneus communis close to the tuber calcanei. The source of vascularisation and innervation (Fig. 4/d) originated from the $\mathrm{m}$. flexor digitorum superficialis and tiny branches entered the medial surface of the additional head. They are branches from the a. et $\mathrm{v}$. femoris caudalis and from the $\mathrm{n}$. tibialis.

\section{Discussion}

When comparing the findings of Spoor and B a doux (1989) concerning the presence of the additional head at the $\mathrm{m}$. flexor digitorum superficialis in the dog and hyena with our findings, even if in only one male goat, it has to be stated that they are almost identical with regard to their external morphology, origin, attachment, and blood supply sources. An exception is only $\mathrm{m}$. soleus, which in the male goat was developed to the same extent as in the other sheep and goats used. This muscle, however, is absent in the Canidae and Hyenidae and according to S poor and B a doux (1989) it is replaced by the additional head of the the $\mathrm{m}$. flexor digitorum superficialis.

What name can be given to the additional head for the $\mathrm{m}$. flexor digitorum found in one male goat, when the original $\mathrm{m}$. soleus is present? Is it the case of a doubled $\mathrm{m}$. soleus with a superficial and deep part, or rather a rare presence of the caput accessorium of the $\mathrm{m}$. flexor digitorum superficialis? In the literature (Ellenberger and B aum 1943; Kolda 1950; Koch 1960; Getty 1975; Nickel et al. 1986) or NAV (1994) the caput accessorium at the $\mathrm{m}$. flexor digitorum superficialis on the hind limb has not been reported in domestic mammals, with the exception of Spoor and Badoux (1989) who described it only in the dog and hyena. As in these two carnivore species and in the male goat, the additional head originated from the muscle belly of the m. flexor digitorum superficialis and terminated in the tendo calcaneus communis by two short thin tendons. It has the same source of vacularisation and innervation as the flexor superficialis muscle, which is in a similar state to e.g. the dog.

The presence of the caput accessorium on the $\mathrm{m}$. flexor digitorum superficialis of the hind limb in the male goat tested, will probably have its origin in its prenatal or phylogenetic development.

\section{Nález prídavnej hlavy m. flexor digitorum superficialis u kozy}

$\mathrm{V}$ práci sa dokumentuje ojedinelý nález prídavnej hlavy $\mathrm{m}$. flexor digitorum superficialis na panvovej končatine u samca kozy. Diskutuje sa jeho možná klasifikácia.

\section{References}

BARONE, R. 1908: Anatomie compareé des mammiféres domestiques. II. Arthrologie et Myologie. Lab. d'anat. École Nat. Vet. Lyon, $1045 \mathrm{p}$.

DYCE, K. M., SACK, W. O., WENSING, C. G. J. 1987: Textbook of Veterinary Anatomy. W. B. Saunders Comp., Philadelphia, $820 \mathrm{p}$.

ELLENBERGER, W., BAUM, H. 1943: Handbuch der vergleichenden Anatomie der Haustiere. 8 Aufl., Spinger Verlag, Berlin, $1155 \mathrm{p}$.

EVANS, H. E. 1993: Miller,s Anatomy of the Dog. 3rd ed., W. B. Saunders Comp., Philadelphia, 1113 p.

GETTY, R. 1975: Sisson and Grosman,s the Anatomy of the domestic Animals. 5th ed., Philadelphia, 2095 p.

KOCH, T. 1960: Lehrbuch der Veterinär-anatomie. Bd. I. VEB Gustav Fischer Jena, 380 p.

KOLDA, J. 1950: Srovnávací anatomie zviŕat domácích. Arthrologie a myologie. VŠV Brno, 426 p.

KÖNIG, H. E.1992: Anatomie der Katze. Gustav Fischer Verlag, Stuttgart, 222 p.

NICKEL, R., SCHUMMER, A., SEIFERLE, E. 1986: The Anatomy of the Domestic Mammals. I. Vol. The locomotor system of the domestic mammals. Verlag Paul Parey, Berlin, Hamburg, 499 p. 
NOMINA ANATOMIA VETERINARIA, 1994, IVth ed., Zürich, Ithaca, New York, 198 p.

SCHWARZE, E. 1960: Kompendium der Veterinär-Anatomie. Bd. I. VEB Gustav Fischer Verlag Jena, 322 p.

SPOOR, C. F., BADOUX, D. M. 1989: The M. Soleus in the Domestic Dog (Canis familiaris). Anat. Histol. Embryol. 18: 27-31 
Plate I.

Rajtová V., Danko J.: An additional... pp. 79-81.
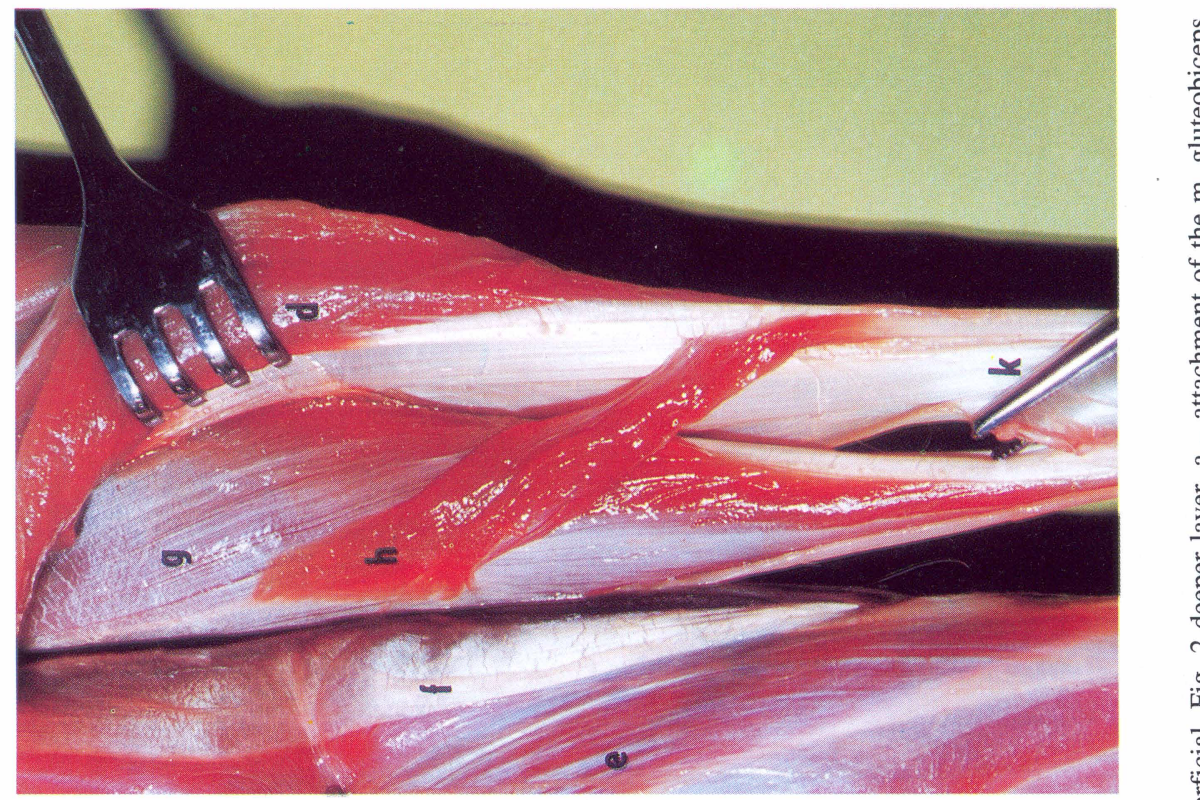

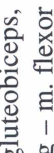

घं

4

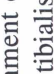

冚

莳

1

$\varpi$

षี

突

离

यु

N

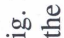

证范

. त्ञ

逭

言 离

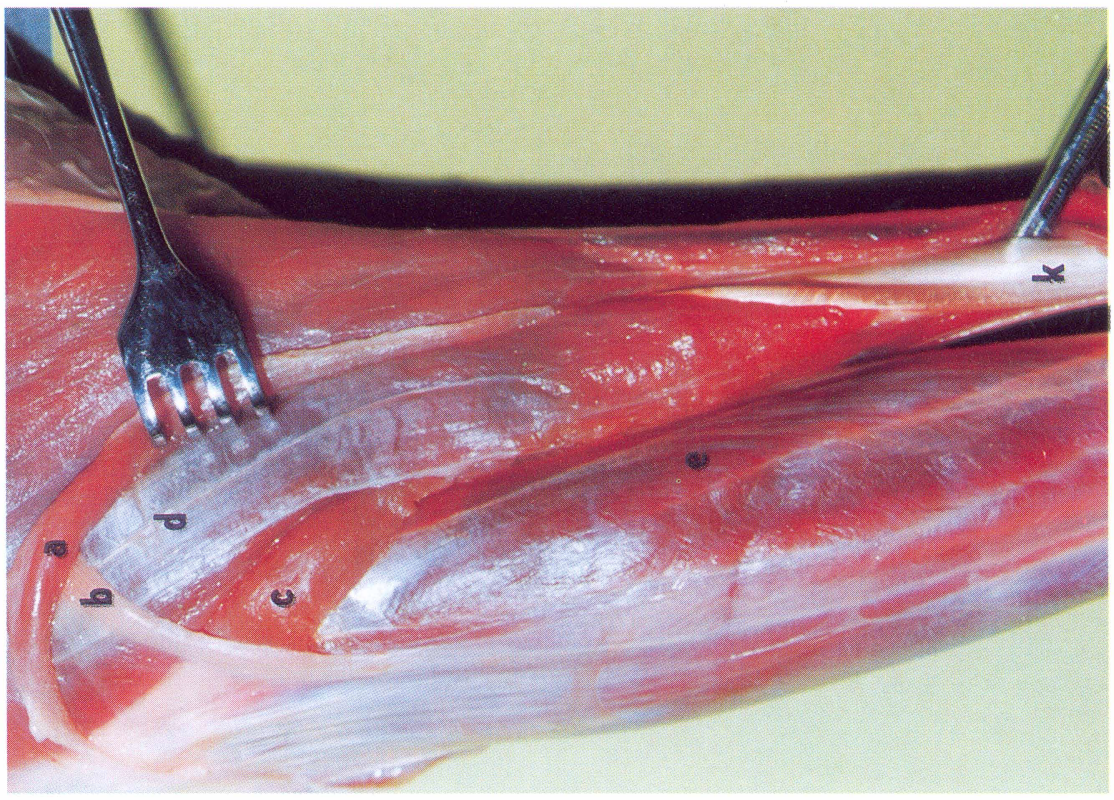

证向

茖产

ํำ

घ

눌

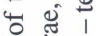

s

䂧

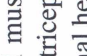

픕

总 1

ㅁ 워

$\nsubseteq 00$

पे

主

岂

군

式色

등

ㄱ. 일

$\therefore$ 更

क $\dot{1}$ 응

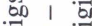


Plate II.

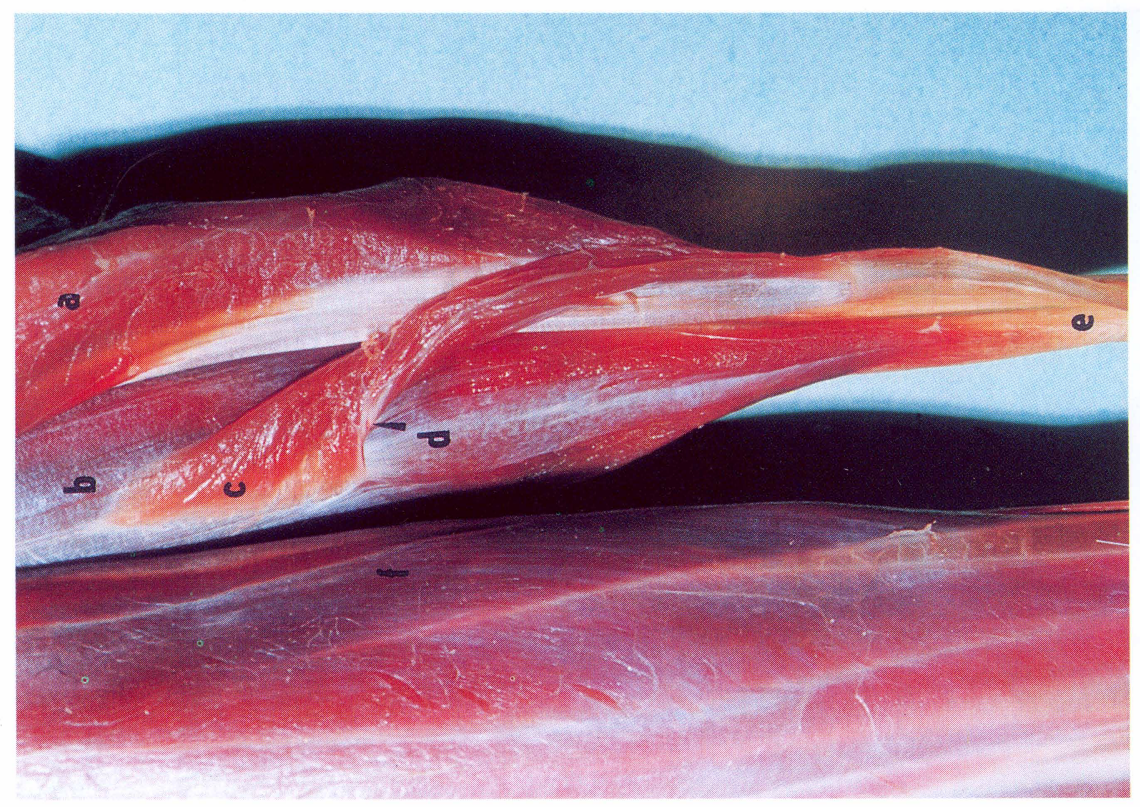

$\stackrel{0}{3} \frac{0}{1}$

$\cong$

䎡

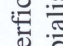

范

क

的

은 글

$\because$

ธิ ฮี

这 -

घ่

1 .

ค ฮ

:ีี

एँ

翟

on

घं बं

불

⿶

를

局

1 兵

政 1

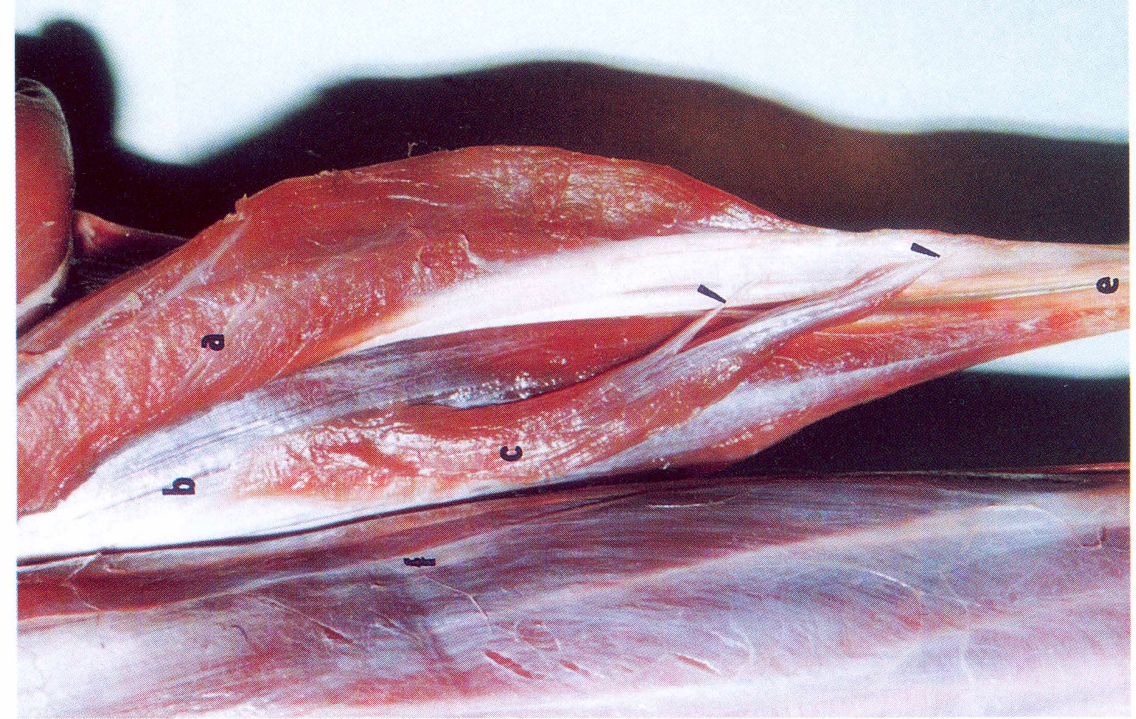

ชี

o

สี

छ

을

Ð

范

즘

卷 冚

巳

पै

$3 \cong$

氜息

정 질

తึ

+

ल

漓总苋 